\title{
MINIMIZATION OF DIRECT COSTS IN THE CONSTRUCTION OF TORRENT CONTROL STRUCTURES
}

\author{
Nada Dragović, Tijana Vulević, Mirjana Todosijević, Stanimir Kostadinov, Miodrag Zlatić
}

Original scientific paper

The most important elements in the planning of the implementation of the torrent (flood) control projects which need to be estimated are time, costs (budget) and resource required. These three elements are interactive: a shorter duration of structure construction causes additional resources engagement and increased costs, and vice versa - greater costs provide a shorter duration of construction. This paper analysis direct project cost minimization for four torrent control projects. The construction duration and the dynamic plan of project activities have been determined using the CPM method of network planning. The optimization problem - minimization of direct cost of construction subject to constraints such as: given deadline, precedence constraints, and upper and lower bounded duration time of activities is solved using linear programming and Matlab toolbox. Our results show that applied methods ensure significant cost savings, which is an important challenge in the construction management.

Keywords: cost minimization; CPM method; linear programming; torrent control

Minimiziranje direktnih troškova izgradnje objekata za zaštitu od poplava

Izvorni znanstveni članak

Najvažniji elemeni u planiranju provedbe projekata kontrole od bujica (poplava) su procjena vremena, troškova (buđžeta) i resursa. Ova tri elementa su interaktivna: kraće trajanje izgradnje strukture uzrokuje angažman dodatnih resursa i povećanje troškova i obrnuto, veći troškovi dovode do kraćeg trajanja gradnje. Ovaj rad se bavi minimiziranjem direktnih troškova projekta na primjeru četiri projekta kontrole bujičnih poplava. Trajanje gradnje i dinamički plan projektnih aktivnosti su određeni pomoću CMP metode mrežnog planiranja. Optimizacijski problem - minimiziranje direktnih troškova gradnje, uz ograničenja kao što su: zadan rok, redoslijed aktivnosti, gornja i donja ograničenja vremena trajanja aktivnosti, riješen je primjenom linearnog programiranja i sučelja Matlaba. Dobiveni rezultati pokazuju da primijenjene metode osiguravaju značajne uštede što je važan izazov organizacije građenja.

Ključne riječi: CPM metoda; linearno programiranje; minimzacija troškova; uređenje bujica

\section{Introduction}

Torrential floods are the most frequently occurring natural hazard causing significant human lives, environmental and economic losses [1]. Reduction or avoidance of flood-related losses through structural works and non-structural measures are a fundamental task of flood management [2]. While non-structural measures use knowledge, practice or agreement to reduce flood risks and impacts [3], structural flood control works are engineering solutions which include construction of transversal and longitudinal structure in the upper and the lower part of the watershed (e.g. check dams, levees, reservoirs, riverbed regulations).

Construction of flood control structures in the riverbed includes a sequence of activities which must be performed timely, due to a number of negative impacts that floods have on the population and the environment. Project activities are an important project scheduling component which is characterized by precedence constraints, duration and resource requirements [4]. Precedence constraints are related to activity start time which must be no earlier than before all the precedence activities are completed $[4,5]$. All project activities have a duration which could be changed, depending on the amount of resource utilization (material, labour, mechanization). The shorter duration causes additional resources engagement and increased costs, and vice versa - the greater costs provide shorter activity duration.

A significant factor for flood control project success, besides time, are costs and their estimation. This factor is important to provide funds to support projects and check projects acceptability. Thus, the way to accomplish the project successfully is keeping the project within estimated costs and prescribed schedule [6]. According to Long [7] successful project is a project completed on time, within budget and in accordance with specifications. The project manager is faced with a problem of wellbalancing between time and cost criteria. The interdependence of these two elements represents a challenge for the planners to organize project activities and find a plan which will optimize the time-cost ratio [8]. Primarily, they must opt for one of the project scheduling approaches: non-delay approach, based on the activity execution of the project estimated time without deferring other activities or delay approach, based on delaying non-critical activities using their slack (float) [9]. The dilemma which approach to choose, depends on the objectives which could be related to time [10], cost $[11 \div 15]$ or resource usage $[16,17]$.

If the aim of the flood construction project is to be completed before the project due date, it could be achieved by crashing project activities which require allocating more resources than it is planned [18]. In this paper, we considered cost based objective - minimizing project costs subject to a given deadline, known as a discrete version of time-cost trade-off problem [19, 20]. Cost-based objectives have been considered in [21] where authors intended to find minimal cost schedule and optimal project crashing curve for highway construction project, considering some additional project characteristics such as external time constraints for particular activities and bonuses/penalties for early/delayed project completion. In [14] the authors minimized total project costs subject to deadline constraints, considering a "what if" scenarios. In [22] the authors strove to find project schedule which maximizes the expected present value of project cash flows. 
Solution procedures which can be used are an exact algorithm, heuristic and meta-heuristic algorithm.

Heuristic methods with less computing effort solve the problem, but they do not guarantee the optimal solution as opposed to the method of mathematical programming such as linear programming non-linear programming, mixed-integer linear programming integer or dynamic programming [23].

The goal of this study was to minimize project costs subject to a given deadline, on the example of four torrent control construction projects, using the project scheduling technique - Critical Path Method (CPM method) and linear programming (LP) optimization method.

\section{Construction project used for the analysis}

In this paper, we considered cost optimization problem for four flood construction projects. Two of these projects refer to the construction of the longitudinal structure (riverbed regulations) and the other two on the construction of a transversal structure (check dams) in the riverbed.

The Belocrkvanska River is a right tributary of the Likodra River in Western Serbia characterized by high transport capacity for sediments. In order to protect the settlements and the major road, the Project of Belocrkvanska River regulation is ordered by owner and consists of works undertaken to form lined channel in stone in cement mortar, 220,00 meters long.

A project of Guvanski Creek regulation (right tributary of the Danube River) has as the main objective to protect important roads from flood water causing traffic disruptions. This flood protection project implies forming riverbed lined by concrete in a length of 202,53 meters and banks by stone in cement mortar.

The other two projects are transverse construction projects which contain check dam construction in the Lukavica River (the right tributary of the Kolubara River) and Ljubovija River (the right tributary of the Drina River). For analysis is selected Check dam No. 1 in the Lukavica River, planned by the Lukavica River regulation Project as a construction in stone in cement mortar with effective height $h_{k}=3,0 \mathrm{~m}$. Check dam in the Tornička River (belongs to the Ljubovija River Watershed) is one of 14 check dams planned to reduce sediment transport and accumulation in the lower part of the main flow, to regulate torrential flood regime and protect river regulation through Ljubovija. The Project is divided into six phases and required significant funds. All projects are divided into activities whose direct cost and duration time are given in Tab. 1 and Tab. 2.

\section{Applied methods}

In order to reduce direct project costs, CPM method and LP technique are applied. CPM method is one of the widely used planning tools and techniques in the construction building. This method is one of the basic methods of network planning used to schedule a set of project activities [18].

CPM method establishes the deterministic duration of the activity which depends on the amount of the resources allocated to that activity. It provides useful information for effective project planning such as critical path (the longest path), free float and total float $[25,26]$. Activities which are not on the critical path have a float, slack or "an extra time available on a schedule" [27]. The total float represents an amount of time remaining for activity delay without affecting the overall project duration. This is a crucial factor for project managers who strive to stay on schedule by adjusting the budget and allocating resources [28].

The above-mentioned characteristics of CPM method as well as better visibility of the available resources, control and coordination of the project, are necessary when planning the construction of the structures for torrent control [29].

The LP was developed in 1939. by a Russian mathematician, Kantorovich, L. V, whereas Dantzig, G. B. contributed to its further theoretical development and the application of the method. Kelley, J. E. and Fulkerson, D. R. are the pioneers of the formulation of the optimization problem considering the time-cost ratio, as an LP model [30].

LP technique represents an efficient way to reduce project costs, which could be achieved minimizing timecost function under the constraints that guarantee a desired project completion time [14]. Model for problem solving is formulated as [31]:

$\min Z=(C m)_{i j}+c_{i j} \times\left((t m)_{i j}-(t)_{i j}\right)$,

Subject to the constraints:

$$
\begin{aligned}
& E_{j}-E_{i}-(t)_{i j} \geq 0, \\
& E_{1}=0 \text { and } E_{n}=T_{p}, \\
& (t m) \leq(\mathrm{t})_{i j} \leq(t k)_{i j}, \\
& \sum(t k)_{i j}=T_{p}, \\
& C_{i j}=\frac{(c k)_{i j}-(\mathrm{cm})_{i j}}{(t m)_{i j}-(t k)_{i j}},
\end{aligned}
$$

where, $Z$ presents desired project cost calculated using Eq. (1); $E_{i}$ and $E_{j}$ given in Eq. (2) are the earliest and latest event times for each event, while $t_{i j}$ is desired time for the completion of the activity $i-j ;(t m)_{i j}$ is minimum possible activity duration (corresponds to time in the network diagram); $(t k)_{i j}$ is maximum possible activity duration; $T_{p}$ presents desired project completion time; $c_{\mathrm{ij}}$ presents costs of activity duration extensions; $(\mathrm{cm})_{i j}$ is direct cost of activity with minimum possible duration and $(c k)_{i j}$ is direct cost of activity with maximum possible duration.

The constraints in Eq. (4) ensure that desired completion time for action $i-j$ is bounded from above by maximal possible activity duration $(t k)_{i j}$ and bounded from below by minimal possible duration of activity $(\mathrm{tm})_{i j}$. Minimum possible duration is duration which corresponds to time in the network diagram (obtained using the CPM method) and maximal possible duration is a result of extending non-critical activities using their total float when these activities become critical. The constraint in Eq. (5) states that the total time of activities on the critical path is equivalent to desired time to project 
Table 1 Time-cost trade-off data for riverbed regulation Projects

\begin{tabular}{|c|c|c|c|c|c|c|}
\hline \multicolumn{2}{|c|}{ Activity } & \multicolumn{2}{|c|}{ Duration } & \multicolumn{2}{|c|}{ Direct costs } & \multirow{2}{*}{$\begin{array}{c}\begin{array}{c}\text { Costs of } \\
\text { extension }\end{array} \\
\begin{array}{c}C i j \\
(€ / \text { day })\end{array}\end{array}$} \\
\hline Mark & $\begin{array}{c}\text { Precedence } \\
\text { relation } \\
(i-j) \\
\end{array}$ & $\begin{array}{l}\text { Lower limit } \\
\qquad \begin{array}{c}(\mathrm{tm})_{i j} \\
(\text { day })\end{array}\end{array}$ & $\begin{array}{l}\text { Upper limit } \\
(t k)_{i j} \\
(\text { day })\end{array}$ & $\begin{array}{c}(\mathrm{Cm})_{i j} \\
(€)\end{array}$ & $\begin{array}{c}(C k)_{i j} \\
(€)\end{array}$ & \\
\hline \multicolumn{7}{|c|}{ Belocrkvanska River } \\
\hline $\mathrm{B}$ & $2-3$ & 4 & 4 & 1085,05 & 1085,05 & - \\
\hline $\mathrm{C}$ & $2-4$ & 1 & 1 & 178,31 & 178,31 & - \\
\hline $\mathrm{D}$ & $3-5$ & 8 & 8 & 1842,02 & 1842,02 & - \\
\hline $\mathrm{E}$ & $5-6$ & 9 & 9 & 3257,36 & 3257,36 & - \\
\hline $\mathrm{F}$ & $4-7$ & 15 & 20 & 6631,38 & 4973,54 & 331,57 \\
\hline $\mathrm{G}$ & $6-8$ & 4 & 4 & 5303,54 & 5303,54 & - \\
\hline $\mathrm{H}$ & $8-9$ & 3 & 3 & 8381,42 & 8381,42 & - \\
\hline $\mathrm{I}$ & $7-10$ & 12 & 17 & 6940,84 & 5034,19 & 381,33 \\
\hline $\mathrm{J}$ & $9-10$ & 5 & 5 & 4226,31 & 4226,31 & - \\
\hline $\mathrm{K}$ & $10-11$ & 6 & 6 & 7153,89 & 7153,89 & - \\
\hline $\mathrm{L}$ & $11-12$ & 10 & 30 & 2486,15 & 1312,44 & 76,32 \\
\hline $\mathrm{M}$ & $12-13$ & 25 & 45 & 50758,12 & 38099,00 & 310,67 \\
\hline $\mathrm{N}$ & $11-13$ & 55 & 55 & 2660,19 & 2660,19 & - \\
\hline \multicolumn{7}{|c|}{ Guvanski Creek } \\
\hline $\mathrm{B}$ & $2-3$ & 5 & 5 & 574,57 & 574,57 & - \\
\hline $\mathrm{C}$ & $2-4$ & 4 & 7 & 617,74 & 360,61 & 85,71 \\
\hline $\mathrm{D}$ & $3-5$ & 12 & 12 & 2126,60 & 2126,60 & - \\
\hline$E$ & $4-6$ & 5 & 8 & 2100,35 & 1319,02 & 260,44 \\
\hline $\mathrm{F}$ & $6-8$ & 9 & 12 & 2108,89 & 1570,00 & 179,63 \\
\hline $\mathrm{G}$ & $5-7$ & 1 & 1 & 263,55 & 263,55 & - \\
\hline $\mathrm{H}$ & $7-9$ & 5 & 5 & 2668,32 & 2668,32 & - \\
\hline I & $9-10$ & 2 & 2 & 412,80 & 412,80 & - \\
\hline $\mathrm{J}$ & $8-11$ & 6 & 9 & 1049,26 & 699,86 & 116,47 \\
\hline $\mathrm{K}$ & $11-12$ & 18 & 21 & 22490,96 & 19315,98 & 1058,33 \\
\hline $\mathrm{L}$ & $10-12$ & 20 & 20 & 9311,79 & 9311,79 & - \\
\hline $\mathrm{M}$ & $12-13$ & 18 & 18 & 13131,02 & 13131,02 & - \\
\hline $\mathrm{N}$ & $13-14$ & 1 & 1 & 71,60 & 71,60 & - \\
\hline
\end{tabular}

completion. The constraints in Eq. (4) ensure that desired completion time for action $i-j$ is bounded from above by maximal possible activity duration $(t k)_{i j}$ and bounded from below by minimal possible duration of activity $(\mathrm{tm})_{i j}$. Minimum possible duration is duration which corresponds to time in the network diagram (obtained using the CPM method) and maximal possible duration is the result of extending non-critical activities using their total float when these activities become critical. The constraint in Eq. (5) states that the total time of activities on the critical path is equivalent to desired time for project completion.

\section{Results and discussion}

In this paper, we consider a deadline problem. Firstly, we used a CPM method to illustrate logical dependencies of the activities of four soil erosion and torrent control projects as a precedence relation $(i-j)$.

The Project of the Belocrkvanska River regulation consists of preparatory, main and final works which "must be performed in a well-defined order" [24]. It represents a construction project, broken into 15 activities, namely: A) opening the construction site, B) cutting down trees and removing stumps, C) clearing undergrowth, D) hand digging of earth for structure foundations, E) mechanical digging of earth for regulation, F) hand digging of earth for regulation, $\mathrm{G}$ ) preparation and installation of excavated soil embankment, $\mathrm{H}$ ) removal of excess excavated material, I) making an outflow structure and cascade No. 1, J) making a gabion cover for the ensuring outflow structure, K) making a concrete wall for footing of quay walls, L) making a gravel bedding, M) coating of major and minor regulation riverbed with stone in cement mortar, N) grassing and humus dressing of slopes, cuttings, O) project acceptance (final inspection). In this network, arcs represent activities, nodes represent events, while the topology of network illustrates precedence constraints [28].

There are four paths in the network diagram: path 1) A-B-D-E-G-H-J-K-L-M-O, path 2) A-B-D-E-G-H-J-K-NO, path 3) A-C-F-I-K-L-M-O, and path 4) A-C-F-I-K-NO. Summing the duration time of critical activities $(t k)_{i j}$ (given in Tab. 1) which are lying on the longest path in the network (path 2) project duration time is obtained as $T p=98$ days. Every project activity had a specified amount of resources required for performing the activity, and the specified duration (time unit: day) as well as the costs (cost unit: $€$ ) (Tab. 1). If more resources are allocated to the activity, the duration of the activity decreases and the corresponding costs of the activity increase [32]. On the other hand, the extension of the duration of activity leads to the cost decrease.

We consider the direct costs of the activities which are related to the individual activities [18] and include: material costs, labor and mechanization costs, the costs of preparation works, previous works, and the administrative costs. Costs of the project starting activity: opening the construction site and project final activity: project acceptance (final inspection) are not considered due to the 
fact that they cannot be precisely determined. Resources (labor, material, and machinery) cost are obtained by multiplying measured quantities by the unit cost of each item. Total direct costs of the Project of the
Belocrkvanska River regulation, with a normal duration of the activity (correspond to the time in the network diagram), are estimated as $138274,66 €$.

Table 2 Time-cost trade-off data for check dam construction Projects

\begin{tabular}{|c|c|c|c|c|c|c|}
\hline \multicolumn{2}{|c|}{ Activity } & \multicolumn{2}{|c|}{ Duration } & \multicolumn{2}{|c|}{ Direct costs } & \multirow{2}{*}{$\begin{array}{c}\begin{array}{c}\text { Costs of } \\
\text { extension }\end{array} \\
\begin{array}{c}C_{i j} \\
(€ / \text { day })\end{array}\end{array}$} \\
\hline Mark & $\begin{array}{l}\text { Precedence } \\
\text { relation } \\
(i-j)\end{array}$ & $\begin{array}{l}\text { Lower limit } \\
\qquad \begin{array}{l}(\mathrm{tm})_{i j} \\
(\text { day })\end{array}\end{array}$ & $\begin{array}{l}\text { Upper limit } \\
(t k)_{i j} \\
\text { (day) }\end{array}$ & $\begin{array}{c}(\mathrm{Cm})_{i j} \\
(€)\end{array}$ & $\begin{array}{c}(C k)_{i j} \\
(€)\end{array}$ & \\
\hline \multicolumn{7}{|c|}{ Lukavica River } \\
\hline $\mathrm{B}$ & $2-3$ & 1 & 1 & 95,76 & 95,76 & - \\
\hline $\mathrm{C}$ & $2-4$ & 2 & 2 & 171,59 & 171,59 & - \\
\hline $\mathrm{D}$ & $3-5$ & 5 & 10 & 934,45 & 467,23 & 93,44 \\
\hline$E$ & $4-6$ & 4 & 4 & 457,09 & 457,09 & - \\
\hline $\mathrm{F}$ & $6-8$ & 3 & 3 & 402,25 & 402,25 & - \\
\hline $\mathrm{G}$ & $5-7$ & 2 & 2 & 123,01 & 123,01 & - \\
\hline $\mathrm{X}$ & $7-9$ & 1 & 3 & 134,08 & 44,46 & 44,70 \\
\hline $\mathrm{H}$ & $9-10$ & 15 & 15 & 8252,74 & 8252,74 & - \\
\hline I & $8-11$ & 8 & 11 & 2494,88 & 1793,20 & 233,89 \\
\hline $\mathrm{J}$ & $11-12$ & 3 & 6 & 499,14 & 420,64 & 26,17 \\
\hline \multicolumn{7}{|c|}{ Tornička River } \\
\hline B & $2-3$ & 5 & 5 & 395,13 & 395,13 & - \\
\hline $\mathrm{C}$ & $2-4$ & 3 & 6 & 240,23 & 120,12 & 40,04 \\
\hline $\mathrm{D}$ & $3-5$ & 6 & 6 & 1106,72 & 1106,72 & - \\
\hline$E$ & $5-7$ & 4 & 4 & 704,77 & 704,77 & - \\
\hline $\mathrm{F}$ & $4-6$ & 5 & 8 & 801,95 & 501,22 & 100,24 \\
\hline $\mathrm{G}$ & $7-9$ & 1 & 1 & 50,00 & 50,00 & - \\
\hline $\mathrm{H}$ & $6-8$ & 3 & 4 & 752,91 & 543,85 & 209,05 \\
\hline I & $9-11$ & 12 & 12 & 10307,26 & 10307,26 & - \\
\hline $\mathrm{J}$ & $8-10$ & 2 & 5 & 277,11 & 110,84 & 55,42 \\
\hline $\mathrm{K}$ & $10-12$ & 10 & 13 & 11102,86 & 8528,11 & 858,25 \\
\hline $\mathrm{L}$ & $12-13$ & 3 & 6 & 2020,92 & 1010,46 & 336,82 \\
\hline $\mathrm{M}$ & $11-13$ & 1 & 1 & 260,24 & 260,24 & - \\
\hline
\end{tabular}

Minimization of costs for a given project duration is achieved by using the total float of non-critical activities. The critical activities determine the project duration and its completion time must remain unchanged in solving this problem. The non-critical activities, i.e. those whose duration can be extended for a certain number of time units, are activities F, I, L and M.

Applying linear programming and setting the objective function and constraints in Matlab toolbox, the problem is solved. The results of optimization are identifying the value of all the project activity duration and the earliest and the latest starting date.

The function is obtained as follows:

$\min Z=138274,66+463,13+224,16 \times(12-17)+$

$+310,67 \times(25-45)=138274,66-8534,15=129740,51 €$

After the minimization of costs of the project implementation of the longitudinal structure construction - regulation of the Belocrkvanska River, we got that the minimum of the function $\mathrm{Z}$ equals $138274,66 €$. The time of the critical activities, as well as the activity $t_{4-7}$, remained the same while the duration of the following activities was changed: $t_{7-10}=17$ and $t_{12-13}=20$. The extension of the duration of these activities resulted in the reduction of costs. After the optimization, the duration of the project corresponds to the duration established by the method of network planning or $T p=98$.
Direct project costs after applying optimization method are reduced from $138274,66 €$ to $129740,51 €$. A cost reduction of $8534,15 €$ secures cost savings of 6,17 $\%$. Direct cost curve before applying the optimization method and the curve obtained by minimization of direct costs for a given duration of the project realization by applying the method of linear programming are displayed in Fig. 1.

Using the same method costs for other three projects are obtained. A project of Guvanski Creek regulation consists of 15 activities, whose duration time of 68 days is estimated using network planning technique. Activity duration time and project cost are shown in Tab. 1. Project activities form two paths into network plan: 1) AC-E-F-J-K-M-N and path 2) A-B-D-G-H-I-L-M-N as the longest path. Applying optimization method direct costs of Guvanski Creek regulation project are reduced from 59 $927,45 €$ to $53752,47 €(5,58 \%)$. It was achieved that activity $\mathrm{K}$ was extended for three days, leading to cost reduction of $3174,98 €$ (Fig. 2). Check dam No. 1 in the Lukavica River is planned by the Lukavica River regulation Project as a construction in stone in cement mortar with effective height $h k=3,0 \mathrm{~m}$. Project duration time is estimated by network planning technique as 29 days and project cost as $13564,99 €$. Duration times of project activities, as well as direct project costs, are shown in Tab. 2. This project includes 11 activities, whose network diagram consists of four paths: path 1) AB-D-H-K, path 2) A-B-D-X-I-J-K, path 3) A-C-E-F-X-I- 
J-K and the path 4) A-C-E-F-H-K as a critical path. Cost optimization was based on the utilization of the total float of activities D and I, where the costs of extensions have the highest value. The results are cost reduction on 12 $396,09 €$ or for $8,62 \%$ (Fig. 3).

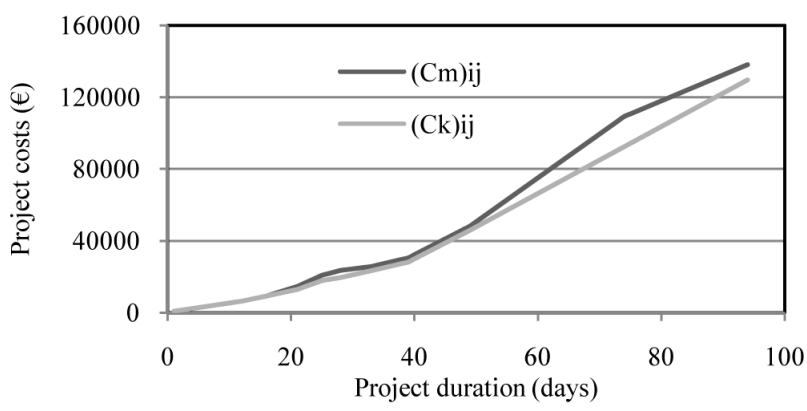

Figure 1 Direct project costs of the Belocrkvanska River regulation Project: before optimization $-(\mathrm{Cm})_{i j}$ and after optimization $(\mathrm{Ck})_{i j}$

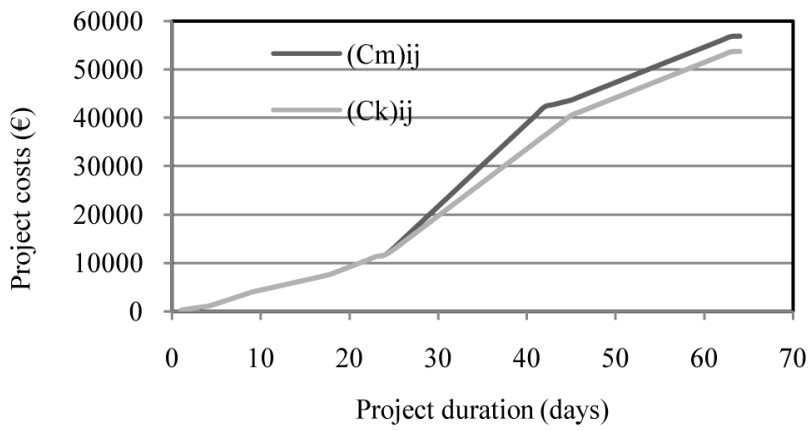

Figure 2 Direct project costs of Guvanski Creek regulation Project: before optimization $-(\mathrm{Cm})_{\mathrm{ij}}$ and after optimization $(\mathrm{Ck})_{i j}$

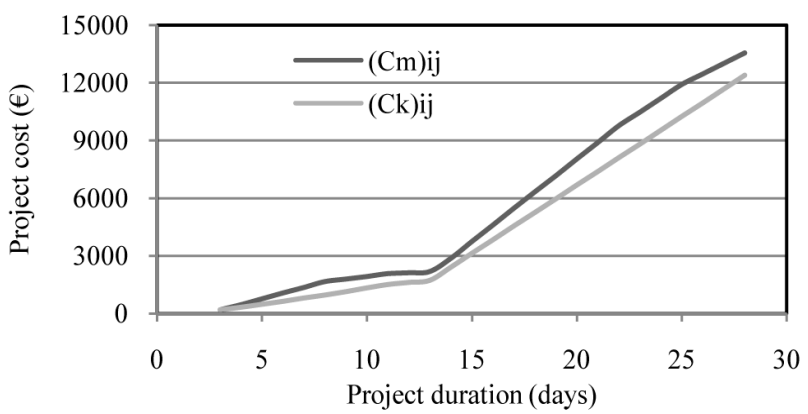

Figure 3 Direct project costs of Check dam construction in Lukavica River: before optimization $-(\mathrm{Cm})_{i j}$ and after optimization $(\mathrm{Ck})_{i j}$

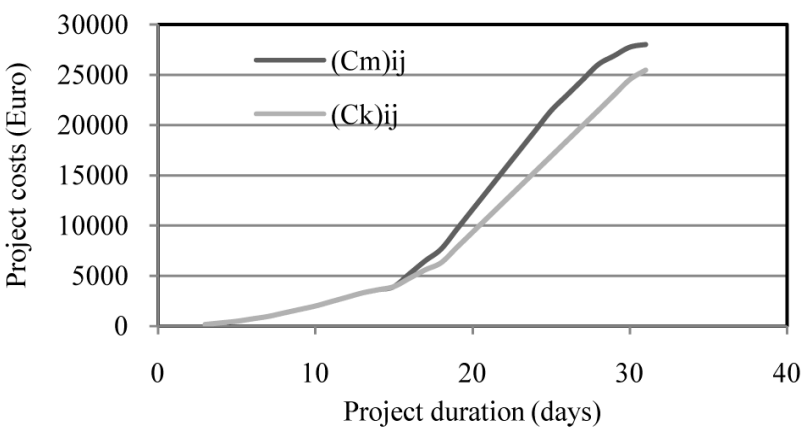

Figure 4 Direct project costs of Check dam construction in the Tornička River: before optimization $-(\mathrm{Cm})_{i j}$ and after optimization $(\mathrm{Ck})_{i j}$

One of the objects planned in the Ljubovija River watershed is concrete check dam No. 1 in the Tornička River tributary. Presenting the project activities in the form of the network plan, two paths are registered: path 1) A-B- D-E-G-I-M-N and path 2) A-C-F-H-J-K-L-N. The path 1) lasts 32 days and determines project duration. Direct project costs are estimated as $28020,10 €$. Details regarding duration times and costs of project activities are shown in Tab. 2. Cost optimization that was performed consisted in the extension of activity $\mathrm{K}$ for three days. Costs are reduced by $9,19 \%$, i.e. by $2574,75 €$ as it is shown in Fig. 4.

The results show that direct cost minimization within the given deadline for a torrent control project using linear programming methods leads to the cost reduction. The direct project costs, considered in this paper are reduced by $6,17 \%$ and $5,58 \%$ for river regulation projects and by $8,62 \%$ and $9,19 \%$ for check dam construction project. These percentages primarily depend on the quantity of works, which determinate project cost and cost reduction percentages. The percentage costs reduction is lower than in some other construction industries, because of job quantity as well as the specific technology of these objects influencing lower parallelization of project activities.

\section{Conclusion}

An integral part of the project and a crucial factor for its success are costs and their estimation. This paper presents the possibility to minimize the direct project costs subject to a given deadline, applying CPM method and LP optimization method. The real life projects - the construction of torrent control structures in order to reduce the risk of floods and sediment accumulation are used as an example. The result shows a reduction in project costs by $6,17 \%$ and $5,58 \%$ for riverbed regulation projects while check dam construction projects costs are reduced by $8,62 \%$ and $9,19 \%$. In planning the implementation of projects for the regulation of torrential flows a greater decrease in direct costs is not possible due to the smaller number of the listed types of works and their quantity as well as the technology in the construction works of this type of structures that does not allow greater parallelization [33].

\section{Acknowledgements}

This paper was released as a part of the project No. 43007 (subproject No. 16), funded by the Ministry of Education, Science and Technological Development of the Republic of Serbia.

\section{References}

[1] Ristić, R.; Kostadinov, S.; Abolmasov, B.; Dragicević, S.; Trivan, G.; Radić, B.; Trifunović, M.; Radosavljević, Z. Torrential floods and town and country planning in Serbia. // Natural Hazards and Earth System. 12, 1 (2012), pp. 2335. https://doi.org/10.5194/nhess-12-23-2012

[2] Petry, B. Coping with floods: complementarity of structural and non-structural measures. // Flood Defence '2002, Proceedings of the $2^{\text {nd }}$ International Symposium on Flood Defence / Beijing, 2002, pp. 60-71.

[3] UNISDR (United Nations International Strategy for Disaster Reduction). Terminology on Disaster Risk Reduction. http://www.unisdr.org/files/7817_UNISDR TerminologyEnglish.pdf (13.12. 2013). 
[4] Weglarz, J.; Józefowska, J.; Mika, M.; Waligóra, G. Project scheduling with finite and infinite number of activity processing. // European Journal of Operational Research, 208, 3 (2011), pp. 177-205.

https://doi.org/10./j.ejor.2010.03.037

[5] Zhou, J.; Love, P. E. D.; Wang, X.; Teo, K. L.; Irani, Z. A review of methods and algorithms for optimizing construction scheduling. // Journal of the Operational Research Society, 64, 8 (2013), pp. 1091-1105. https://doi.org/10.1057/jors.2012.174

[6] Odeh, A. M.; Battaineh, H. T. Causes of construction delay: traditional contracts. // International Journal of Project Management. 20, 1 (2002), pp. 67-73.

[7] Long, N. D.; Ogunlana, S.; Quang, T.; Lam, K. C. Large construction projects in developing countries: a case study from Vietnam. // International Journal of Project Management. 22, 7 (2004), pp. 553-561. https://doi.org/10.1016/j.ijproman.2004.03.004

[8] Burns, S. A; Liu, L.; Feng, C. W. The LP/IP hybrid method for construction time- cost trade-off analysis. // Construction Management and Economics, 14, 3 (1996), pp. 265-276. DOI: 10.1080/014461996373511

[9] Zwikael, O.; Cohen. Y.; Sadeh, A. Non-delay scheduling as a managerial approach for managing projects. // International Journal of Project Management. 24, 4 (2006), pp. 330-336. https://doi.org/10.1016/j.ijproman.2005.11.002

[10] Neuman, K.; Schwindt, C.; Zimmermann, J. Recent results on resource constrained project scheduling with time windows: Models, solution methods, and applications. // Central European Journal of Operations Research. 10, 2 (2002), pp. 113-148.

[11] Archutan, N. R.; Hardjawidjaja, A. Project Scheduling under Time Dependent Costs - A Branch and Bound Scheduling Algorithm. // Annals of Operations Research. 108, 1-4 (2001), pp.55-74.

[12] Maniezzo, V.; Mingozzi, A. The project scheduling problem with irregular starting time cost. // Operations Research Letters. 25, 4 (1999), pp. 175-182.

[13] Möhring, R. H.; Schulz, A. S.; Stork, F.; Uetz, M. Solving project scheduling problem by minimum cut computations. // Management Science. 49, 3 (2003), pp. 330-350.

[14] Moussourakis, J.; Haksever, C. Flexible Model for Time/Cost Tradeoff Problem. // Journal of Construction Engineering and Management. 130, 3 (2004), pp. 307-314. https://doi.org/10.1061/(ASCE)0733-9364(2004)130:3(307)

[15] Xu, J.; Zheng, H.; Zeng, Z.; Wu, S.; Shen, M. Discrete time-cost-environment trade-off problem for large scale construction systems with multiple modes under fuzzy uncertainty and its application to Jingping-II Hydroelectric project. // International Journal of Project Management. 30, 8 (2012), pp. 950-966. https://doi.org/10.1016/j.jproman.2012.01.019

[16] Akkan, C.; Drexl, A.; Kimms, A. Network decomposition based benchmark results for the descrete time-cost tradeoff problem. // European Journal of Operational Research. 165, 2 (2005), pp. 339-358. https://doi.org/10.1016/j.ejor.2004.04.006

[17] Andrijanić, T.; Dragović, N.; Todosijević, M. Optimizacija angažovanja radne snage pri planiranju izvođenja radova na regulaciji Jelašničke reke. // Glasnik Šumarskog fakulteta. 106 (2012), pp. 29-40. https://doi.org/10.2298/GSF1206029A

[18] Kim, J. Y.; Kang, C. W.; H. I. K. A practical approach to project scheduling: considering the potential quality loss cost in the time-cost tradeoff problem. // International Journal of Project Management. 30, 2 (2012), pp. 264-272. https://doi.org/10.1016./j.ijproman.2011.05.004

[19] Möhring, R. H. Minimizing Costs of Resource Requirements in Project Networks Subject to a Fixed Completion Time. // Operations Research. 32, 1 (1984), pp. 89-120.
[20] Hafizoglu, A. B.; Azizoglu, M. Linear programming based approaches for the discrete time/cost trade-off problem in project network. // Journal of the Operational Research Society. 61, 4 (2010), pp. 676-685. https://doi.org/10.1057/jors.2009.20

[21] Sakellaropoulos, S.; Chassiakkos, A. P. Project time-cost analysis under generalized precedence relations. // Advances in Engineering Software. 35, 10-11 (2004), pp. 715-724. https://doi.org/10.1016/j.advengsoft.2004.03.01

[22] Sobel, M. J.; Szmerekovsky, J. G.; Tilson, V. Scheduling projects with stochastic activity duration to maximize expected net present value. // European Journal of Operational Research. 198, 3 (2009), pp. 697-705. https://doi.org/10.1016/j.ejor.2008.10.004

[23] Feng, C. W.; Liu, L.; Burns, S. A. Stochastic construction Time-Cost Trade-off Analysis. // Journal of Computing in Civil Engineering. 14, 2 (2000), pp. 117-126.

[24] Kelly, J. E. Critical path scheduling and planning: Mathematical basis. // Operations Research. 9, 3 (1961), pp. 296-320.

[25] Babu, A. J. G.; Suresh, N. Project management with time, cost and quality considerations. // European Journal of Operational Research. 88, 2 (1996), pp. 320-327.

[26] Kastor, A.; Siracoulis, K. The effectiveness of resource leveling tools for Resource Constraint Project Scheduling Problem. // International Journal of Project Management. 27, 5 (2009), pp. 493-500. https://doi.org/10.1016/j.jproman.2008.08.006

[27] The Critical Path Method. // Programming and scheduling techniques / Uher, T.E. University of New South Wales Press Ld: Australia, 2003. pp. 38-68.

[28] Yang, H.-H.; Chen, Y.-L. Finding the critical path in an activity network with time-switch constraints. // European Journal of Operational Research. 120, 3 (2000), pp. 603613.

[29] Dragović, N. Evaluation of CPM Method in the constructions in torrential watersheds. // SYM-OP-IS '94, Proceedings of XXI Yugoslav Symposium of Operational Research / Kotor, 1994, pp. 803-806.

[30] Klanšek, U.; Pšunder, M. MINLP optimization model for the nonlinear discrete time-cost trade-off problem. // Advances in Engineering Software. 48 (2002), pp. 6-16. https://doi.org/10.1016./j.advengsoft.2012.01.006

[31] Petrić, J. Operaciona istraživanja. Naučna knjiga, Beograd, 1987.

[32] Liu, L.; Burns, S.A.; Feng, C.-W. Construction Time-Cost Trade-Off Analysis using LP/IP hybrid method. // Journal of Construction Engineering and Management. 121, 4 (1995), pp. 438-446.

[33] Dragović, N. Optimization of torrent management project realization. Doctoral Thesis, University of Belgrade, Faculty of Forestry, 2001.

\section{Authors' addresses}

Full. Prof. Nada Dragović, Ph.D. Assist. Tijana Vulević, dipl. ing. Assist. Prof. Mirjana Todosijević, Ph.D. Full. Prof. Stanimir Kostadinov, Ph.D. Full. Prof. Miodrag Zlatić, Ph.D. University of Belgrade, Faculty of Forestry, Kneza Višeslava 1, 11000 Belgrade, Serbia E-mail: nada.dragovic@sfb.bg.ac.rs E-mail: tijana.andrijanic@sfb.bg.ac.rs E-mail: mirjana.todosijevic@sfb.bg.ac.rs E-mail: stanimir.kostadinov@sfb.bg.ac.rs E-mail: miodrag.zlatic@sfb.bg.ac.rs 